\title{
Integrating Facebook Social Network for the Statistics Course: Its Outcomes of Undergraduate Students' Prince of Songkla University Pattani Campus, Thailand
}

\author{
Afifi Lateh ${ }^{1}$ \\ ${ }^{1}$ Department of Educational Evaluation and Research, Faculty of Education, Prince of Songkla University \\ Pattani Campus, Thailand \\ Correspondence: Department of Educational Evaluation and Research, Faculty of Education, Prince of Songkla \\ University Pattani Campus, Thailand. Tel: 66-8-0544-6558. E-mail: afifi_lateh@yahoo.com
}

Received: January 13, 2014 Accepted: January 30, 2014 Online Published: February 26, 2014

doi:10.5539/ass.v10n6p212

URL: http://dx.doi.org/10.5539/ass.v10n6p212

\begin{abstract}
The objective of the study was to integrate Facebook social network for the Statistics course of undergraduate students' Prince of Songkla University Pattani campus, Thailand. The study investigated the interaction of the students' academic learning with Facebook social network and the relationship between the laboratory scores, the achievement scores, and the interactive scores of learning with Facebook social network. Then, the study compared the difference of the student's achievement scores after learning with Facebook social network by group interaction with laboratory score functioning as a covariate, and evaluated satisfaction of students who are learning with Facebook social network. The participants were the twenty-nine second year's undergraduate students majoring in Information Technology and Educational Evaluation of Faculty of Education, Prince of Songkla University Pattani campus, Thailand. The research instruments were teaching course plans with questions for being posted on Facebook wall, the mid-term examination test, the record form of learning interaction, and the student's satisfaction questionnaire. From this study, although the average of the achievement scores are not different when classified by the interaction group in which the covariate variable as the laboratory score, the use of Facebook integrated in teaching is an effective tool in increasing the students' interaction as seen from the relationship among those of three variables. Implications of the results are discussed.
\end{abstract}

Keywords: statistics course, learning achievement, Facebook social network

\section{Introduction}

Facebook is considered an online communication tool which can create the user's profile to do many online activities with people on this social network (Boyd \& Eillison, 2007). It is found that people access Facebook to update their status, post pictures, chatting with family and friends, and playing games every day. Nowadays, Facebook becomes a leading social networking site which is accesses by more than 955 million users as shown in June 2013; moreover, in Asia, Indonesia is the country with the highest amount of Facebook users, whereas Thailand is ranked as the third with 18.2 million users (Facebook Overview Statistics, 2013). The behavior of Facebook users in each country is similar. For example, they spend more than one hour per day on Facebook (Lamp, Ellison, \& Steinfield, 2006; Ellison, Steinfiled, \& Lampe, 2007; Joinson, 2008; Christofides, Muise, \& Desmarais, 2009; Mazman \& Usluel, 2010). The female users spend more time on Facebook than the male ones with statistical significance (Muise, Chirtofides, \& Desmarais, 2009). The young Facebook users tend to spend more time on it than the old ones. Besides, it is found that the female users post the pictures or update the status rather than the men do with statistical significance (Joinson, 2008). Most of the Facebook users allow only their friends to access them by setting the privacy in their account (Young \& Quan-Hasse, 2009). At the same time, they show the information about their former educational institute and relationship status in the percentage of 95 and 88 respectively while they show their telephone only 21 percent (Ellison et al., 2007). The male Facebook users always specify their interest in women rather than men whereas the female Facebook users do not specify any interest in gender in their basic information (Wang, Moon, Kwon, Evans, \& Stefanone, 2010).

Although the Facebook users usually link to their formerly known friends, they do not use it to add new friends (Pempek, Yermolayeva, \& Calvert, 2009; Ellison et al., 2007). They also deny the friend requests of the strangers 
through the online network. However, they like to find new friends in the online community rather than new friends in the real world (Lenhart \& Madden, 2007) and they use Facebook to observe the people's movement rather than post the status (Pempek et al., 2009). On the other hand, it is found that the users believe that Facebook can encourage them to learn English well (Kabilan, Ahmad, \& ZainolAbidin, 2010; Omar, Embi, \& Yunus, 2012; Yunus \& Salehi, 2012). The students, moreover, have a positive attitude towards the study when they have interaction with the teachers via Facebook previously (Mazer, Murphy, \& Simonds, 2009; Sturgeon \& Walker, 2009). Nevertheless, some researchers show that the high number of friends in Facebook makes the users stressful, unhappy and nervous to look forward to the message from others, and worried about missing some news unless they access their Facebook all the time. Furthermore, some of Facebook users are full of stress and anxiousness because of being treated by the other users like being denied, depressed as well as worried and jealous towards other Facebook users' lifestyles. For the benefit of using Facebook, it can relieve the problems' stress of the users, but it wastes the time affecting the study, work, interaction with people, family and themselves, and their habit.

Because of this, several researchers still believes that Facebook can be a tool helping student's gain assistance in doing assignment from the teachers or the lecturers. It is also a channel for sharing learning resources. Hence, this study applies the online social network, Facebook, to schooling for the groups of students. The objective of the study was to integrate Facebook social network into teaching statistics to the undergraduate students of the faculty of Education, Prince of Songkla University, Pattani campus. It aims to study students' interaction towards learning with Facebook social network, and relationship between the laboratory scores, the achievement scores as well as the learning interactive scores resulted from using Facebook online social network. Furthermore, the study was compares the differences of the students' achievement scores after Facebook online social network is used in teaching. The students are classified by the learning interactive scores of which the laboratory scores function as a covariate.

\section{Methodology}

The participants were the twenty-nine second year's undergraduate students majoring in Information Technology and Educational Evaluation of Faculty of Education, Prince of Songkla University Pattani campus, Thailand. All of them registered in the course of Statistical Designs for Educational Research in the second semester of the academic year 2011. The content used in the research consists of Hypothesis Testing Reviews, Completely Randomized Design, and Randomized Block Design. The lessons last seven weeks or twenty-eight periods: fourteen periods for theories and another fourteen periods for practices. Moreover, the variables taken in this research are teaching management by using Facebook considered as an independent variable, and the laboratory, the achievement, the learning interactive and the students' satisfaction scores grouped as dependent variables. For the research instruments, the study uses 1) teaching course plan with questions for posting on Facebook after each lesson is finished on Hypothesis Testing Reviews, Completely Randomized Design, and Randomized Block Design, 2) mid-term examination test resulted from teaching with Facebook consisting of four items of the subjective test, 3) record form of learning interaction for collecting the communication after questions is posted, and 4) the students' satisfaction questionnaire towards teaching with Facebook consisting of eighteen items. The study lasts two months starting from October $25^{\text {th }}, 2011$ to December $30^{\text {th }}, 2011$. The data of laboratory scores were collected from theoretical and practical exercises scores after each lesson is finished; the achievement scores and the learning interactive scores were collected from mid-term examination scores and the record scoring of learning interaction, respectively.

This study aims to investigate the interaction on Facebook online social network; therefore, students have to access the internet every period after the class is finished. Then, the study sets agreement with them about accessing Facebook. However, they are familiar with it because of their society in nowadays. This will not be any obstacles for the study. The study creates the group in Facebook and names it as Stat Design in order to encourage the students communicate, exchange ideas, post images and videos, send messages, and share useful information about their lessons. At the same time, all of the students must inform their Facebook profile's name to the group for firstly signing because it will be easy for him to record their learning activities participation on it accurately. For the relationship between the laboratory scores, the achievement scores, and the interaction scores of learning through Facebook, this study measures the learning achievement from both the theoretical and laboratory exercises contributed after finishing each lesson and the achievement test of the mid-term examination. In addition, the study values posting messages of each student including giving opinions, asking and answering some questions, and clicking Like button as a measurement for the interaction scores. Finally, the satisfaction scores of the learners towards integrating Facebook for teaching are assessed at the end of the course. 
The study finds out the mean and standard deviation scores to show the central and distribution values of the interaction's numbers, the laboratory scores, the achievement scores and the interaction scores, and also indicates the level of the learners' satisfaction towards integrating Facebook for teaching. Additionally, this study uses the statistic to test the hypothesis about the central value of the population in term of the learning interaction, and Pearson Correlation Coefficient to illustrate the relationship between the laboratory scores, the achievement scores and the scores of learning interaction through using Facebook. In the same way, also takes the Analysis of Covariance to compare the differences of the achievement scores classified by a group of interaction which carries the laboratory scores as an uncontrollable intervening factor.

\section{Results and Discussion}

This study reveals the results of students' academic learning interaction with Facebook social network on the lessons in the course of Experimental Designs for Educational Research, measures the interaction from posting the students' messages which are about expressing their ideas, answering the fourteen questions and clicking Like in the created group on Facebook as shown in the Figure 1 and Figure 2. On the other hand, the Figure 3 shows the number of students' academic learning interaction with Facebook social network.

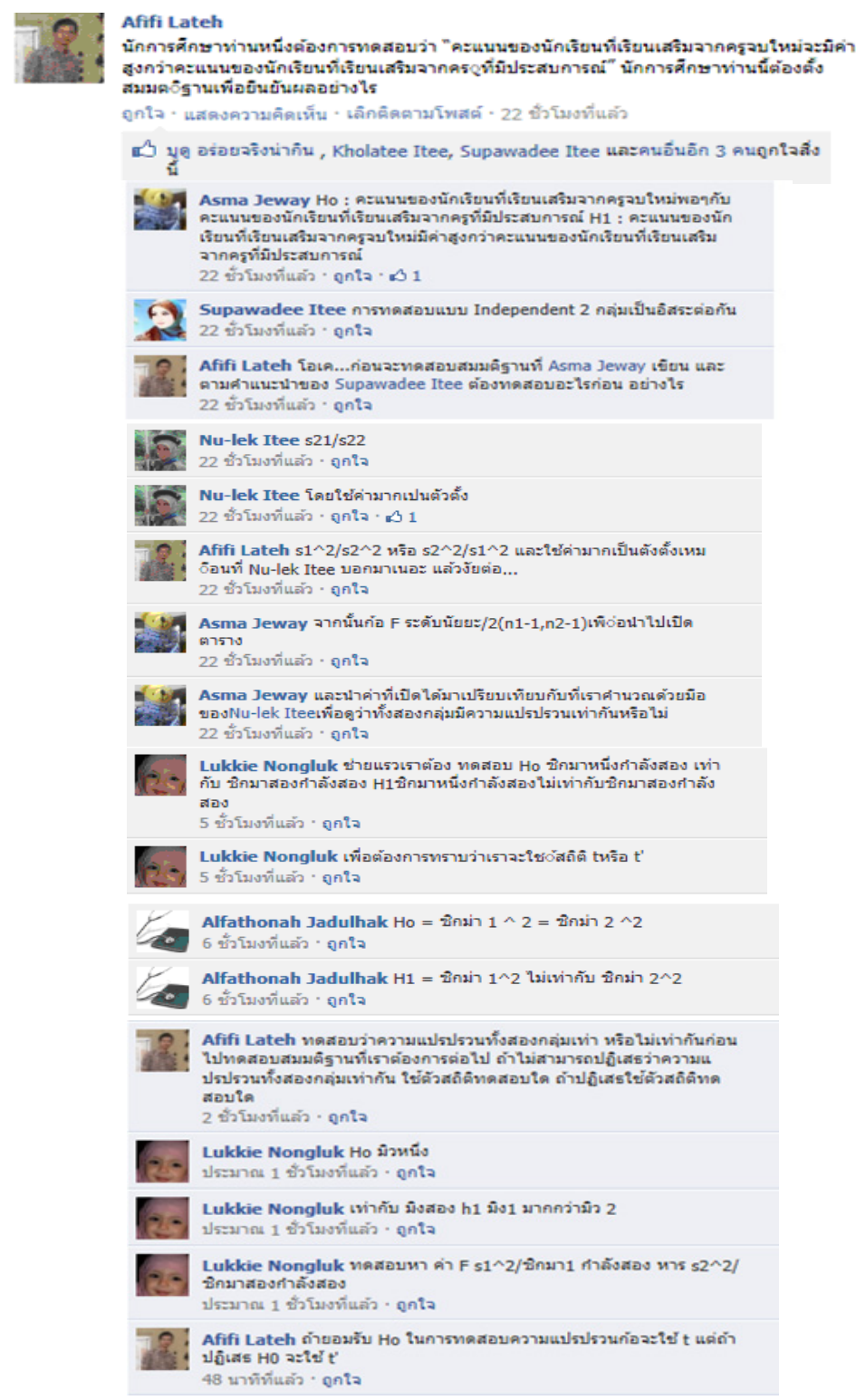

Figure 1. Example of posting the $1^{\text {st }}$ question including expressing ideas, answering the question and clicking like 
การเล่นเกม 2 รูปแบบ แบ่งเป็นกลุ่มละ 23 และ 22 คน ตามฝ่าดับ ผลการวิเคราะห์ คะแนนพัฒนาการเป็นดังรูปข้างล่าง ลอง อะบีียผ

แ แห๊กรูปภาพ เพิ่มสถานที แก้ไข

จูกใจ - แสดงความคิดเท็น - เลิกติดตามโพสต์

Alfathonah Jadulhak, D Dow Maplo

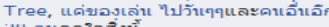

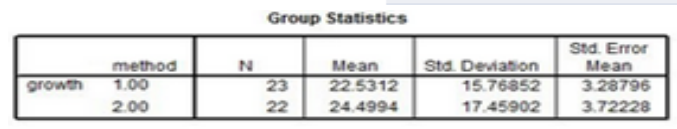

\begin{tabular}{|c|c|c|c|c|c|c|c|c|c|c|}
\hline \multicolumn{11}{|c|}{ Independent Samples Test } \\
\hline & & \multicolumn{2}{|c|}{$\begin{array}{l}\text { Levene's Test for } \\
\text { Equalify of variances }\end{array}$} & \multicolumn{7}{|c|}{ thest for Equality of Means } \\
\hline & & \multirow[b]{2}{*}{$\mathbf{F}$} & \multirow[b]{2}{*}{ sig. } & \multirow[b]{2}{*}{$t$} & \multirow[b]{2}{*}{ at } & \multirow[b]{2}{*}{ Sug (2-tailed) } & \multirow{2}{*}{$\begin{array}{l}\text { Mean } \\
\text { Difference }\end{array}$} & \multirow{2}{*}{$\begin{array}{l}\text { Sta Error } \\
\text { Difference }\end{array}$} & \multicolumn{2}{|c|}{$\begin{array}{l}90 \% \text { Confidence } \\
\text { Interval of the } \\
\text { Difference }\end{array}$} \\
\hline & & & & & & & & & Lower & Upper \\
\hline growen & $\begin{array}{l}\text { Equal variances } \\
\text { assumed } \\
\text { Equal variances } \\
\text { not assumed }\end{array}$ & 590 & .447 & $\begin{array}{l}-397 \\
-396\end{array}$ & $\begin{array}{r}43 \\
42.094\end{array}$ & $\begin{array}{r}.693 \\
.694\end{array}$ & $\begin{array}{l}-1.96828 \\
-1.96828\end{array}$ & $\begin{array}{l}4.95504 \\
4.96549\end{array}$ & $\begin{array}{l}-10.29806 \\
-10.32126\end{array}$ & $\begin{array}{l}6.36150 \\
6.38470\end{array}$ \\
\hline
\end{tabular}

2)

Wijittra Itee สมมติฐาน $\mathrm{Ho}$ : มิว 1 เท่ากับมิว 2 H1: มิว2

23 พฤศจิกายน 2011 เวลา 17:18 . ถูกใจ. 2

Ke. Kholatee Itee ในตาราง Group statistics พบว่าค่าเฉลี่ยกลุ่มที่ 1 22.5312 ส่วนเบี่ยงเบนมาตรฐาน $=15.76852$ และความคลา เคลื่อนมาตรฐาน $=3.28796$ คะแนน

23 พฤศจิกายน 2011 เวลา $17: 30$ น. ' ถูกใจ $ณ 1$

经

Kholatee Itee กลุ่มตัวอย่างเป อิสระต่อกัน คร้าาา

23 พฤศจิกายน 2011 เวลา 17:52

2. Noohlan Ilada ความแปรปรวน ไม่เท่ากันใช้ $t$ ด้านล่าง 23 พฤศจิกายน 2011 เวลา 18:08 น. . ถูกใจ

学

Tiamo Oop องศาเสร

$\mathrm{df}=42.094$ และค่า $\mathrm{p}-$ value $=0.694(\mathrm{sig}$-2tailed $)$ 23 พถศจิการแ 2011 เวลา 18:12 น. . ถูกใจ. 11

F. Nongluk Lanla ค่าเฉลียกลุ่ม 1 เท่ากับ 22.531 23 พฤศจกายน 2011 เวลา 18:18 น. $\cdot$ ถูกใจ $\lll 1$

F. Nongluk Lanla หาค่า $f$ จาก s2^2หารs 1 ^2 52^2หารs $1 \wedge 2$ 2011 เวลา 18:20

4. Tiamo Oop ค่าเฉลี่ยกลุ่ม $2=24.4994$

23 พฤศจิกายน 2011 เวลา 18:23
4. Arnee Neii ค่าf $=1.18$ คร้า 23 พถศจิกายน 2011 เวลา 18:25 น. ถูกใจ ณ 1

(a)

Arnee Neii นำค่า $f$ ที่ได้ มา เที่ยบในตารางเพื่อทดสอบความ แปรปรวน 23 พฤศจิกายน 2011 เวลา 18:27 น. ' ถูกใจ

(ब)

Arnee Neii อิอิ 23 พเศศจิกายน 2011 เวลา 18:29 น. . ถูกใจ 11

.41 Lita Watpon ทาง เพราะการ เล่นเกม 2 รูปแบบ 23 พฤศจิกายน 2011 เวลา $18: 35$ น. * ถูกใจ ณ 1

(ल) Candy Nana เพื่อนๆค่ะ อยาก ทราบว่าความแปรปรวนไม่เท่ากันดู ได้อย่างไร+_+ 23 พฤศจีกายน 2011 เวลา 20:18 น. * ถูกใ

9. Wijittra Itee คูที่ค่า $t$ ถ้าเท่ากัน แสดงว่าความแปรปรวน กันแต่นี้มันไมอ่เท่ากันความ แปรปรวน 2 กลุ่มจ ธงไม่เท่ากัน 23 พฤศจึกายน 2011 เวลา 20:23 น. ' ถกใจ - 32

Tiamo Oop ถ้าค่า $t 2$ กล่มไม เท่ากันใช้ค่า $\mathrm{df}$ sig maen ตัวล่าง 23 พฤศจีกายน 2011 เวลา 20:29 น. ' ถูกใจ Afifi Lateh แอลฟ่า เท่ากับ 0.10 ไมใชชชกมานะ Wijittra Itee... 23 หจดจกาย 2011 เวลา $20: 29$ . กูกใจ
3. Wijittra Itee ช่ายค่ะที่คิดคือค่า พอจท่า ขออกัยด้วยค่ะ 23 พฤศจิกายน 2011 เวลา 20:33 น. * ถูกใจ

एై Rohanee Khamimah เราใช้ สถิติ f-test ในการดว่าความแปร

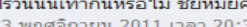
น. . ถูกใจ

(2) Nongluk Lanla ค่าความ แปรปรวนเท่ากัน เพราะค่า $f$ ใน ตาราง เท่ากับ 2.39 ค่า $f$ ที่คำ นวนดัยเท่ากับ 1.18 ดังนี้นจะมัน สามารถปฏีเสธ $h o$ ด้อ 24 พฤศจิกายน 2011 เวลา 16:25 น. · ถูกใจ - 3

Afifi Lateh $\mathrm{HO}$ : มิว 1 เท่ากับ มิว 2 (คะแนนพัณนาการเฉลี่ยของนัก เร็ยนจากกลุ่มที่ 1 และกลู่มที่ 2 ไม่ แตกด่างกัน) $H 1$ : มิว 1 ไม่เข่ากับ มืว 2 (คะแนนพัดนาการเฉสียของ นักเริยนจากกลุมที่ 1 และกล่มที่

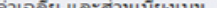
จำนวน 23 คน เท่ากับ 22.53 และ 15.77 ส่วนค่าเฉลี่ย และส่วนเบี่ยง เบนมาตรฐานของนนกเรียนกลุมที่

25 พฤศจิกายน 2011 เวลา 7:07

2. Afifi Lateh ค่า $\mathrm{t}$ เท่ากับ -.397 ค่า Sig. เท่ากับ .693 พึ่งมากกว่า สามารถปภีเสธ $H 0$ นั้นคือ คะแนน พัฒนาการเฉลียจากการฝธก 2 รูป แบบไม่แตกต่างกันอย่างมีนัย สาคัญทระดับ 10 25 พฤศจักายน 2011 เวลา 7:13

Figure 2. Example of posting the $5^{\text {th }}$ question including expressing ideas, answering the question and clicking like 


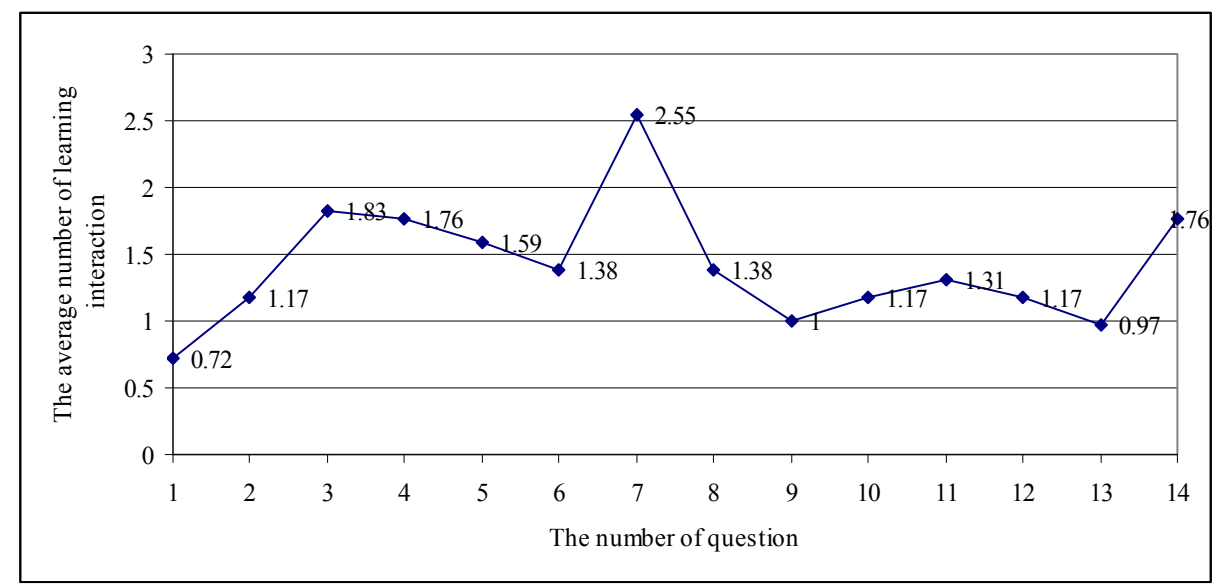

Figure 3. The average number of students' academic learning interaction with Facebook social network

Since there is biased distribution from normal distribution on the number of students' academic learning interaction with Facebook social network, the Wilcoxon Signed Ranks Test was used. It is found that the number of students' academic learning interaction with Facebook social network at the $3^{\text {rd }}, 4^{\text {th }}, 5^{\text {th }}, 7^{\text {th }}, 8^{\text {th }}$, and $14^{\text {th }}$ items is more than 1 time with statistical significance. The average times of them are $1.83,1.76,1.59,2.55,1.39$ and 1.76 while the standard deviations are 2.07, 1.33, 1.48, 1.49, 1.08 and 1.68 respectively (Wilcoxon Statistic $=$ $120.0,177.5,108.5,329.0,90.0$ and 112.0 respectively). For the students' academic learning interaction as a whole, there are more than 14 times from 14 question items posted in the study. Its mean is 19.76 whereas the standard deviation is 9.49 with the statistical significance at 0.01 level (Wilcoxon Statistic $=323.5$ ).

The relationship between the laboratory scores, the achievement scores and the learning interactive scores with academic learning Facebook social network on the lessons in the Statistical Designs for Educational Research course designed for 7 weeks is evaluated from the scores of the assigned exercises and the mid-term examination relating to the lessons. The total of the laboratory scores and the achievement scores is 50 . However, the learning interactive scores are given as 2 points if the students propose some ideas towards the questions posted and given as 1 point if the students click like button towards some of them. The study is discovered that the mean of the laboratory scores resulted from integrating Facebook social network for teaching is 37.47 while its standard deviation is 5.20. Then, the mean of the achievement scores is 21.34 while its standard deviation is 9.87 . At the same time, the mean of the learning interactive scores is 24.38 whereas its standard deviation is 13.35 . When these scores are tested by Pearson Correlation Coefficient, it indicates that the correlation coefficient between the laboratory scores and the achievement scores is 0.63 , the correlation coefficient between the laboratory scores and the learning interactive scores is 0.50 , and the correlation coefficient between the achievement scores and the learning interactive scores is 0.52 with the statistical significance at 0.01 level as stated in Figure 4 and Table 1.

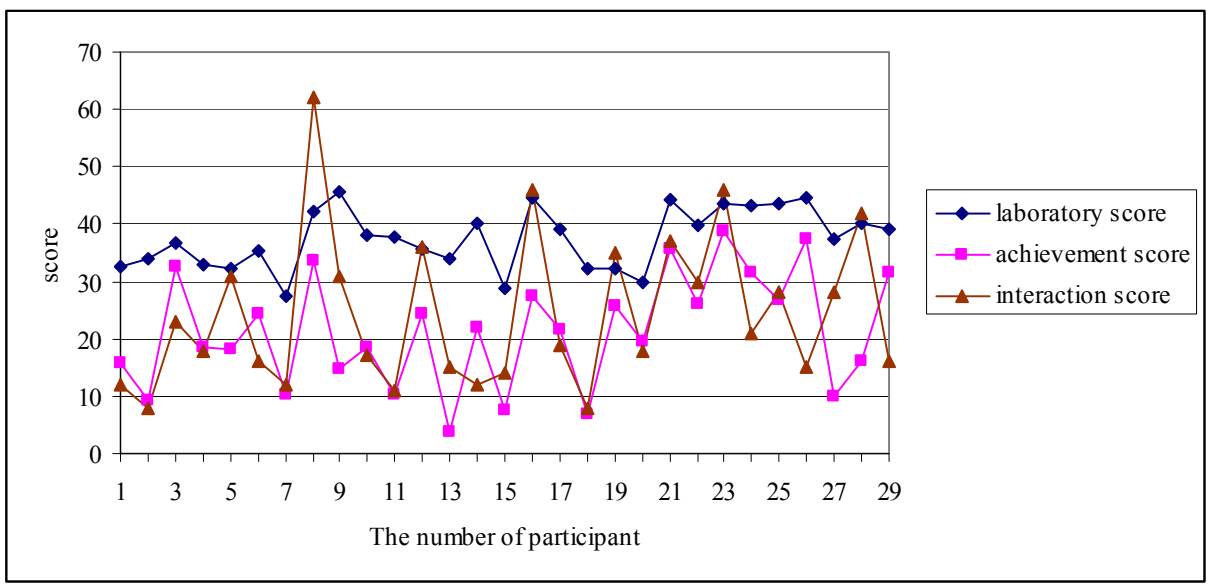

Figure 4. The scores of laboratory, learning achievement and academic learning interactive with Facebook social network 
Table 1. Pearson correlation coefficient between the scores of laboratory, learning achievement and academic learning interactive with Facebook social network

\begin{tabular}{llll}
\hline & laboratory scores & achievement scores & interaction scores \\
\hline laboratory scores & - & & \\
achievement scores & $0.63^{* *}$ & - & - \\
interaction scores & $0.50^{* *}$ & $0.52^{* *}$ & - \\
\hline
\end{tabular}

$* * \mathrm{p}<0.01$

For the result of comparing the laboratory scores and the students' learning achievement scores after integrating Facebook social network for teaching the seven weeks course, the students are classified by the levels of the interaction scores: low, medium, high and very high. The range of the interaction scores are less than 15, 15-28, $29-42$, and more than 42 respectively. It is found that the mean of the low interaction learners' achievement scores is 15.29 and its standard deviation is 6.91. Then, the mean of the medium interaction learners' achievement scores is 29.92 and its standard deviation is 12.71 while the mean of the high interaction learners' achievement scores is 29.86 and its standard deviation is 9.55 . At the same time, the mean of the very high interaction learners' achievement scores is 43.17 and its standard deviation is 7.51.

The laboratory scores considered as an uncontrollable intervening factor which affect the achievement ones are determined as a covariate in order to compare the differences of the learning achievement following by the range of interaction. This judge is examined by Levene test to assess the equality of variances between the groups. It is found that the variances between the groups are not different with the statistical significance at 0.05 level $\left(\mathrm{F}_{3,25}=\right.$ $0.74)$. Besides, the regression coefficient or covariate slope value is 0.75 with 0.05 level $(t=2.29)$. It corresponds to the result of covariance analysis which reveals that the laboratory scores are related to the learning achievement scores with the statistical significance at 0.05 level $(F=5.26)$. These results fortunately follow the basic agreement of the covariance analysis. On the other hand, the mean of comparison values of the students' achievement scores, which are classified by the interaction and contain the laboratory scores as a covariate, after uses Facebook social network as a tool of teaching are not different with the statistical significance $(\mathrm{F}=2.02)$ while the mean of the learning achievement result after the extraneous variables are controlled and the laboratory scores of the interaction range: low, medium, high, and very high are 14.86, 22.76, 22.20 , and 28.77 respectively as Table 2 .

Table 2. The comparison result of the students' achievement scores after integrating Facebook social network into learning the course with the laboratory scores functioning as a covariate

\begin{tabular}{lllll}
\hline Variation Source & $\mathrm{df}$ & $\mathrm{SS}$ & $\mathrm{MS}$ & $\mathrm{F}$ \\
\hline covariate & 1 & 289.53 & 289.53 & $5.26^{*}$ \\
between group & 3 & 341.77 & 113.92 & 2.02 \\
within group & 25 & 1322.10 & 55.09 & \\
total & 28 & 2729.23 & & \\
\hline
\end{tabular}

$* \mathrm{p}<0.05$

The consequence of students' satisfaction towards integrating Facebook social network into the course lasting 7 weeks (14 periods) is indicated that the students are satisfied with it at the high level. Its mean is 3.99 while its standard deviation is 0.51 . When the researcher analyzes the learners' satisfaction in each item, it is found that the students are most contented with the subject matter and the examples posted on the Facebook wall which relate to the content, course description and objectives of which mean is 4.52 and standard deviation 0.51 . Secondly, the students are satisfied with the content and examples order starting the easiest to the hardest at the high level of which mean is 4.38 and standard deviation is 0.67 . For the issue of activities management on Facebook social network, it is opened to the students participate in learning all the time. Its mean and standard deviation are 4.33 and 0.66 respectively. Furthermore, integrating Facebook into the course increases students' comprehension in the lessons, but it is the lowest mean item among those in the high level of satisfaction; the mean is 3.57 while the standard deviation is 1.08 . 


\section{Conclusion}

This study was revealed that the students have learning interaction on Facebook social network more than fourteen times in seven weeks of the study designed. It also shows that the laboratory scores, the achievement scores and the scores of learning interaction by integrating Facebook for teaching are related to each other. When comparing the achievement scores, classified by the learning interaction group and in which the laboratory scores act as a covariate, of each learner after studying through Facebook, there are no differences of the mean with the statistical significance. From this study, although the average of the achievement scores are not different when classified by the interaction group in which the covariate variable as the laboratory score, the use of Facebook integrated in teaching is an effective tool in increasing the students' interaction as seen from the relationship among those of three variables. This result is similar to the study of Bosch (2009) found that the samples who exchange learning media about the subject through Facebook social network can more communicate with the instructor. In addition, Kabilan et al. (2010) found that the undergraduate students of Universiti Sains Malaysia in Malaysia agree with improving four skills of English through the messages posted on the Facebook wall or chatting in the Facebook messenger whereas Omar et al. (2012) informed that Facebook is a good place for sharing information in doing task with positive feedback and an essential tool to encourage English learning interaction. Yunus and Salehi (2012), in the same way, indicated that Facebook group can be used as a tool to improve writing skill of the students, especially when they brainstorm their ideas for a passage. Liu (2010) discovered that Facebook social network becomes one third of the learning channels of the samples which consist of four factors: social engagement, direction communication, speed feedback and relationship building. Moreover, the research of McCharty (2010) was shown that the samples have the condition of learning through Facebook social network based on two factors: peer interaction and academic engagement whereas Coklar (2012) indicated that 27 samples express on the advantages of exchanging learning media through Facebook social network that it encourages them interact to the learners. It was ranked as high as the third out of ten items. Irwin, Ball, and Desbrow (2012) informed that the samples have the learning condition from using Facebook social network in term of rising interaction and participation.

Additionally, Lam (2012) found that the 312 Hi-diploma students attending the course which allow them communicate through Moodle and Facebook have higher motivation in learning with the statistical significance. The factors which increase their motivation are interaction, communication, social relationship and participation. Saikaew, Krutkam, Pattaramanon, Leelathakul, Chaipah, and Chaosakul (2012) also stated that the samples of undergraduate and postgraduate students agree that Facebook social network is both formal and informal learning route for both students and instructors. It can be used for discussion, video or link exchange; moreover, students can set many issues and answer the instructors' questions in the network quickly. Nevertheless, the research of Lateh, karnjanasingha, Anunthai, and Thotong (2012) was still mentioned that there are some variables relating to the index of the behavior and activity using Facebook. They could be health attitude, academic attitude and social one while the variable of age is significantly related to the behavior index of using Facebook, but the variable of students' academic years has no statistically significant relationship to these two indices. For the suggestion of this study, to notice that scoring the interaction by clicking Like on the answers posted on the Facebook wall by other students could not clearly reflect the interaction of the learners. The learning achievement result of the different interaction group providing the unvaried mean when determining the laboratory scores as a covariate could be caused from dividing the overlapping interaction group.

\section{References}

Bosch, T. E. (2009). Using online social networking for teaching and learning: Facebook use at the University of Cape Town. Communicatio, 35, 185-200. http://dx.doi.org/10.1080/02500160903250648

Boyd, D. M., \& Eillison, N. B. (2007). Social network sites: Definition, history, and scholarship. Journal of Computer-Mediated Communication, 13(1), 210-230. http://dx.doi.org/10.1111/j.1083-6101.2007.00393.x

Christofides, E., Muise, A., \& Desmarais, S. (2009). Information disclosure and control on Facebook: Are they two sides of the same coin or two different processes? Cyber Psychology \& Behavior, 12, 341-345. http://dx.doi.org/10.1089/cpb.2008.0226

Coklar, A. N. (2012). Evaluations of students on Facebook as an educational environment. Turkish Online Journal of Qualitative Inquiry, 3, 42-53.

Ellison, N. B., Steinfield, C., \& Lampe, C. (2007). The benefits of Facebook friends: Social capital and college students use of online social network sites. Journal of Computer-Mediated Communication, 12, 1143-1168. http://dx.doi.org/10.1111/j.1083-6101.2007.00367.x

Facebook Statistic. (2013). Retrieved February 23, 2013, from 
http://www.facebook.com/press/info.php?statistics

Irwin, C., Ball, L., \& Desbrow, B. (2012). Students' perceptions of using Facebook as an interactive learning resource at university. Australian Journal of Educational Technology, 28, 1221-1232.

Joinson, A. N. (2008). Looking at, looking up or keeping up with people? Motives and uses of Facebook. Retrieved March 5, 2011, from http://people.bath.ac.uk/aj266/pubs_pdf/1149-joinson.pdf

Kabilan, M. K., Ahmad, N., \& ZainolAbidin, M. J. (2010). Facebook: An online environment for learning of English in institutions of higher education? Internet and Higher Education, 13, 179-187. http://dx.doi.org/10.1016/j.iheduc.2010.07.003

Lam, L. (2012). An innovative research on the usage of Facebook in the higher education context of Hong Kong. The Electronic Journal of E-Learning, 10, 377-386.

Lampe, C., Ellison, N., \& Steinfield, C. (2006). A Face(book) in the crowd: Social searching vs. social browsing. Retrieved March 5, 2011, from http://citeseerx.ist.psu.edu/viewdoc/download?doi=10.1.1.88.7485

Lateh, A., Karnjanasingha, S., Anunthai, J., \& Thothong, S. (2012). Students' attitudes toward Facebook usage in Burapha University. Journal of Education, Prince of Songkla University Pattani campus, 23(3), 80-97.

Lenhart, A., \& Madden, M. (2007). Teens, privacy \& online social networks: How teens manage their online identities and personal information in the age of MySpace. Retrieved March 16, 2011, from http://www.atg.wa.gov/uploadedFiles/Another/Office_Initiatives/Teens,Privacy\%20and\%20Social\%20Net works.pdf

Liu, Y. (2010). Social media tools as a learning resource. Journal of Educational Technology Development and Exchange, 3, 101-114.

Mazer, J. P., Murphy, R. E., \& Simonds, C. J. (2009). The effects of teacher self-disclosure via Facebook on teacher credibility. Learning, Media and Technology, 34, 175-183. http://dx.doi.org/10.1080/17439880902923655

Mazmun, S. G., \& Usluel, Y. K. (2010). Modeling educational usage of Facebook. Computers \&Education, 55, 444-453. http://dx.doi.org/10.1016/j.compedu.2010.02.008

McCharty, J. (2010). Blended learning environments: Using social networking sites to enhance the first year experience. Australian Journal of Educational Technology, 26, 729-740.

Muise, A., Christofides, E., \& Desmarais, S. (2009). More information than you ever wanted: Does Facebook bring out the green-eyed monster of jealousy? Cyber Psychology \& Behavior, 12, 441-444. http://dx.doi.org/10.1089/cpb.2008.0263

Omar, H., Embi, M. A., \& Yunus, M. M. (2012). ESL learners' interaction in an online discussion via Facebook. Asian Social Science, 8(11), 67-74. http://dx.doi.org/10.5539/ass.v8n11p67

Pempek, T. A., Yermolayeva, Y. A., \& Calvert, S. L. (2009). College students' social networking experiences on Facebook. Journal of Applied Developmental Psychology, 30, 227-238. http://dx.doi.org/10.1016/j.appdev.2008.12.010

Saikaew, K. R., Krutkam, W., Pattaramanon, R., Leelathakul, N., Chaipah, K., \& Chaosakul, A. (2012). Using Facebook as a supplementary tool for teaching and learning. Retrieved March 5, 2012, from http://gear.kku.ac.th/ krunapon/research/pub/usingFB4Learning.pdf

Sturgeon, C. M., \& Walker, C. (2009). Faculty on Facebook: Confirm or deny? Retrieved March 5, 2011, from http://www.mtsu.edu/itconf/proceedings/09/Faculty.on.Facebook.Sturgeon-Walker03_29_09.pdf

Wang, S. S., Moon, S., Kwon, K. H., Evans, C. A., \& Stefanone, M. A. (2010). Faceoff: Implications of visual cues on initiating friendship on Facebook. Computers in Human Behavior, 26, 226-234. http://dx.doi.org/10.1016/j.chb.2009.10.001

Young, A. L., \& Quan-Haase, A. (2009). Information revelation and internet privacy concerns on social network sites: A case study of Facebook. Retrieved March 5, 2011, from http://www.iisi.de/fileadmin/IISI/upload/2009/p265.pdf

Yunus, M. M., \& Salehi, H. (2012). The effectiveness of Facebook group on teaching and improving writing: Students' perceptions. International Journal of Education and Information Technologies, 1(6), 87-96.

\section{Copyrights}

Copyright for this article is retained by the author(s), with first publication rights granted to the journal.

This is an open-access article distributed under the terms and conditions of the Creative Commons Attribution license (http://creativecommons.org/licenses/by/3.0/). 